\title{
TONY BOLOS
}

University of Edinburgh

\section{Rolfe King. Obstacles to Divine Revelation. Continuum, 2009.}

If there is a God, then there seems to be significant hindrances or obstacles in the way in which God reveals himself to his creation. What are these obstacles? Can these obstacles be overcome? Are there necessary limits to the way in which God must operate when it comes to divine revelation? If there are necessary limits, is this a feature of the created order or is this a feature of God himself? Given these limitations, what sort of divine acts must God use in order to reveal himself (pp. 1-3)?

In Obstacles to Divine Revelation, Rolfe King provides some stimulating answers to the above questions and, interestingly, brings the discussion to the centre of epistemology. It is the latter contribution, I think, that is unique to King's project. His project begins, however, by answering an essential question: What is revelation? King defines revelation as: "God's self-disclosure, in any form, leading to some kind of awareness, or knowledge, of him" (p. 5).

From this, one might assume that God's options for revealing himself are limitless. However, King rightly notes that God's options are limited given that the people that he wishes to communicate with are also limited (p. 54). If God, for example, chose to reveal himself with distinct clarity and undeniable evidence in the UDFy galaxy (13 billion light years away) it would do little in convincing his creation of himself. So if God does indeed wish to reveal himself (something traditional theism affirms), then he must do so in such a way that reflects the capacities of his limited creation (e.g., by not revealing himself in galaxies to which we will never have access).

So if God's options for revelation are indeed limited, this might be considered the first obstacle to his revelatory plan. This obstacle, as King notes, says nothing about God and everything about his creation. This is why King understands obstacles to divine revelation as: "Any feature of the created order that may either block or hinder a form of divine disclosure, or has in some way to be overcome in order for God to disclose himself." (p. 5). 
These features, whatever they might be, must be located within the created order. But what, exactly, are these features? And how exactly does one go about identifying these features? The two principles that King suggests to identify the features that hinder revelation are the epistemic-revelatory principle (ErP) and the revelatory-context principle (RcP) (pp. 39-40). The former principle claims that epistemic problems concerning evidence (interpreted quite broadly) are an obstacle to divine revelation (p. 9), while RcP claims that a specific context is required in order for God to reveal himself in a way that is comprehensible by his creatures. All obstacles to revelation, according to King, fall into the above categories - they are either epistemic problems or contextual problems (pp. 40-41).

I find ErP more interesting, and more controversial I might add. ErP, for example, makes the claim that God might have difficulty revealing himself insofar as our epistemic position lacks complete discernment of the available evidence. The "Eden parable" illustrates this nicely (pp. 44-47). In the parable the angels are talking amongst themselves about all the different ways in which God might reveal himself to his new creation. Despite the available options, they all seem plagued by the fact that there is no assurance the creatures will trust the revelation (some experience for example) to be evidence of what God is trying to reveal (perhaps that he exists and that he loves them). Scepticism looms, despite the potentially good revelatory intentions.

But, King suggests, there is another option available to God - one that isn't dependent on the difficult task of matching belief with the available evidence. King notes that this option, which he calls direct cognition, might potentially undermine his central claim that there are indeed obstacles to revelation (p. 60). This worry, however, seems unnecessary. Even if there is direct cognition, one might assume that this feature has been corrupted (by sin for example) and thus doesn't always function the way it was intended. This aside, it is King's understanding of Plantinga (as it relates to direct cognition) that deserves more attention.

King's discussion of Plantinga is very interesting, but ultimately, I think, mistaken. King's key claim is that Plantinga's model is (1) a form of direct cognition and that (2) direct cognition should be understood as divine self-testimony. And that in order for testimony to be trusted, (3) there needs to be decisive evidence that the testifier can in fact 
be trusted (pp. 76-77, 100). If (1)-(3) is true, then the problem with Plantinga's model seems obvious. After all, if belief in God is directly acquired by some properly functioning faculty, the belief still wouldn't be warranted, according to King, since there is no evidence that the faculty is in fact functioning properly (p. 78). Without getting into all the nuances of the debate here, I think the point to stress is that (3) is false. Even if Plantinga's model is a form of testimony (which is questionable), not all models in the current epistemology of testimony would concede (3) given that it's not at all clear that there needs to be decisive evidence that the testifier can in fact be trusted. You might think that testimony is noninferential, which is consistent with Plantinga's claim that belief in God is properly basic. Thus, the claim would simply be that there couldn't be any defeating evidence against the testimony of the testifier. This is known as the defeater clause, which Plantinga's model rightly incorporates.

At any rate, however one feels about the above understanding, the point that King is trying to make is that any account of direct cognition is plagued by the issue of trust. And the requirements concerning evidence and the necessity of trust bring us closer to King's position. King's position, then, is that evidence and trust are both necessary given that any (special) revelation necessarily involves testimony (p. 194). This being the case, King provides a solution to the trust problem and claims, as was seen in the critique of Plantinga, that sufficient evidence is needed for trust. King calls this trust-evidentialism (p. 176).

The obvious question is whether God can provide such evidence. But in asking this question, we are immediately faced with a dilemma. The dilemma, as described by King, is that "God cannot give us any evidence for special revelation independently of self-testifying in some way that the evidence is due to him. But we need independent evidence to rationally trust that this purported revelation is from God" (his emphasis, p. 251).

King's response to this is that "although God cannot give us evidence independent of his self-testimony we may be able to find such evidence" (p. 197). This point isn't as confusing or controversial as it sounds. For example, it was argued by King that there are certain limitations in the ways that God can reveal himself given our limitations. This being the case, there must be some necessary structure in which God will reveal himself. And the necessary structure of this revelation must take into account our limitations. So if we can discern what exactly the necessary 
structure of revelation is, we can then know what kind of evidence to look for (see pp. 176-178). King gives several suggestions that I won't recount here (see pp. 177-181, 197, 201-205), but the point that should be taken is that this evidence would provide the basis for what King claims to be central to divine disclosure - trust.

So, then, there is the initial evidence that King finds necessary for trust. But, it seems, we are still plagued with the problem of properly evaluating the evidence that would lead to knowledge of God. After all, it's not objectively clear that the evidence does anything beyond giving the initial trust or confidence to think some divine testimony might be compelling. This is where King's journey-epistemology becomes becomes important. As King notes, "all I can do is to try to find the best grounds on which to base my trust" (p. 200). And this initial trust will be subject to reasons of the heart (suspicions, fears, personal goals, etc. p. 214). So it's a journey in that the evidence (the evidence that initiates trust) is not sufficient to know (in this case perhaps God's existence), but it is both necessary and sufficient to get you on your journey.

While the significance of the arguments presented above depend, I think, on the truth of (3), I find King's Obstacles to Divine Revelation both interesting and compelling. Students and scholars who work in religious epistemology and philosophy of religion will find King's work to be of value as it examines and advances many contemporary issues in those fields. 